\title{
COXEN Score 17
}

National Cancer Institute

\section{Source}

National Cancer Institute. COXEN Score 17. NCI Thesaurus. Code C128214.

A score of 17 on the COXEN Sensitivity Scale. 